\title{
The Complexity of Coexistence
}

\author{
Civilians and Former Combatants in Post-war Sierra \\ Leone \\ Friederike Mieth \\ (Doctorante en anthropologie sociale et culturelle à \\ l'Université Philipps de Marburg)
}

\section{Résumé/Abstract}

[En] Since the end of the civil war in 2002, Sierra Leoneans have experienced a relatively stable peace and it can be considered common knowledge that civilians and former combatants are living in coexistence. During my fieldwork in the country I was however surprised just how positively some people spoke about the postconflict situation. «We have long forgotten about the war », some told me ; others said they were asked to 'forgive and forget' and claimed they already did so. On the other hand, I met individuals who struggled with negative feelings towards former combatants but still argued that coexistence was without alternatives. In addition, while I noticed how former combatants had integrated successfully into several locations, the label 'ex-combatant' still had a particularly negative connotation. Intrigued by these ambiguities I explore in this article the different aspects of coexistence in Sierra Leone more in detail. Based on ethnographic data collected during eight months of fieldwork, the article describes three practices of coexistence in rural and urban locations. The focus on coexistence, unlike more normative terms like reconciliation and reintegration commonly used in the literature about post-conflict contexts, invites to reflect about these practices, rather than evaluate the different arrangements of living together.

Key-Words: Sierra Leone, coexistence, ex-combatants, civilians, reintegration, 'forgive and forget'.

[Fr] Depuis la fin de la guerre civile en 2002, la population de Sierra Leone a bénéficié d'une paix relativement stable et on peut dire que civils et ex-combattants vivent en coexistence. Cependant, au cours de mon travail de terrain, j'ai été surprise de constater à quel point mes interlocuteurs parlaient d'une manière positive de la situation post-conflit. «On a oublié la guerre depuis longtemps » disaient certains, tandis que d'autres soutenaient qu'on leur avait demandé de «pardonner et d'oublier » et que, par conséquent, ils agissaient selon ce principe. D'autres personnes que j'ai rencontrées partagent cependant des sentiments négatifs à l'égard des 
ex-combattants, mais ils soutiennent en même temps qu'une telle coexistence est sans alternative. Alors que j'ai constaté dans plusieurs localités que les anciens combattants s'intègrent avec succès, ce label d' ' ex-combattants » continue à disposer d'une connotation particulièrement négative. Intrigué par ces ambiguïtés, j'explore plus en détail dans cet article les différents modes de coexistence en Sierra Leone. Basé sur des données ethnographiques collectées durant un travail de terrain de huit mois, l'article décrit trois pratiques différentes de coexistence dans des régions rurales et urbaines du pays. L'accent mis sur la coexistence, à la différence d'autres termes normatifs tels que ceux de réconciliation et de réinsertion, couramment utilisés dans la littérature sur les contextes post-conflit, invite à réfléchir sur ces pratiques, plutôt qu'à évaluer ces différents arrangements du vivre ensemble.

Mots-Clés : Sierra Leone, coexistence, ex-combattants, civils, réintégration, pardonner et oublier.

\section{Introduction ${ }^{1}$}

The most instructive moments in ethnographic fieldwork are those when one faces contradictions : of literature and 'field', of people's words and actions, but most importantly of one's own assumptions and reality. This was the case during my fieldwork in Sierra Leone, ten years after the civil war had ended. I struggled to understand people's use of the word 'ex-combatant'. Of those who were called 'excombatants' not all were actually associated with armed groups, while at the same time many of those who fought during the war lived normal lives, and were not regarded as 'ex-combatant'. I also wondered about the usefulness of terms such as reintegration or reconciliation. Some former combatants had reintegrated or integrated into communities successfully, yet others tried to make a living almost separate from the rest of society. Both ways of living could lead to success - and both ways were paved with difficulties - leaving reintegration as a blurry concept at least. And finally, there were communities that lived in peaceful coexistence, and yet villagers had personal, strongly negative feelings towards former combatants, causing me to wonder just how much reconciliation is needed after war: is such a mere 'performance' of coexistence not harmful for individuals? Or, maybe, is 'reconciliation' simply asking too much of victims of extreme violence?

In this article I wish to share some of my observations in order to demonstrate the complexity of coexistence in a post-war society. Rather than evaluating which

\footnotetext{
${ }^{1}$ I want to express my deep gratitude to all Sierra Leoneans who shared their views with me. I want to thank Ishiatu A. Koroma and Doris B. Lebbie for their assistance and advice in Sierra Leone, and Jonah Lipton, Anne Menzel, Edward Mando, and the participants of the workshop Anthropologie historique des pratiques de violence de masse in Paris, November 2011, for their valuable comments. Finally, I want to thank the editors for their comments and patience.
} 
'strategies' or 'goals' are best in facilitating coexistence after war, I focus on how people have found ways to deal with the situation. To understand how people live after war, I argue, one should keep an open mind about the ways people rebuild social relationships. As I will show, certain practices and conceptions of coexistence raise questions with regard to the common understanding of the necessity of reintegration or reconciliation.

This article is based on data gathered through ethnographic fieldwork for a larger research project on dealing with the past after the civil war in Sierra Leone. Over a total of eight months from 2010 to 2012, I have conducted research in mainly three locations: Madina, a small village in the north of the country, Tombodu, a larger village in the east of the country, and Freetown, Sierra Leone's capital. In all of these locations I interacted with a wide range of individuals of all ages: farmers, miners, traders, owners of small businesses, university students, pupils, as well as professionals in fields related to dealing with the past. The majority of my informants can be described as 'civilians' and many were directly affected by the violence. I also spoke with former combatants of all ages and all fighting factions. Introducing these three locations, I will demonstrate how the perception of the relationship between civilians and former combatants can differ significantly within a country. At the same time, I will explore three different practices or ideas in Sierra Leone that help people to live in and make sense of coexistence.

\section{Civil war in Sierra Leone}

The civil war in Sierra Leone lasted for about 11 years from 1991 to $2002^{2}$. In March 1991 a group of fighters entered the eastern part of Sierra Leone from Liberia. The Revolutionary United Front (RUF) was a rebel movement claiming to overthrow the government and liberate the people. Within months however it became apparent that these rebels mainly attacked civilians and forcibly recruited many into their ranks. The government, which after a coup in 1992 was an interim government headed by a group of young military commanders, more or less half-heartedly fought against this rebel movement. Many of the soldiers were in fact recruited from the same background as rebels - young men with limited alternative opportunities - and soon also soldiers were looting villages and perpetrating atrocities, sometimes disguised as rebel attacks, earning them the label sobels, rebel-turned-soldier. Starting mostly in the south of the country, local hunter organisations (widely referred to as kamajors) were formed and took to defending their villages from both rebels and soldiers (Keen, 2005).

\footnotetext{
${ }^{2}$ The war is well documented. See, for example, Abdullah (2004), Coulter (2009), Gberie (2005), Keen (2005), and Richards (1996).
} 
In 1996, largely pushed for by civil society groups, democratic elections took place and a peace agreement was signed between rebels and the government. However, fighting resumed shortly after and in 1997, the government was forced into exile by a joint soldier/rebel junta which was again ousted out of Freetown a year later by West African peacekeeping forces. Although the kamajors had been formalised under the defense ministry and were fighting together with the peacekeepers the tactics they employed were sometimes indistinguishable from those of other fighting factions. Once deployed outside their region of origin, they took to looting and killing as well. A second peace accord in 1999 also failed to end the war which was eventually stopped after United Nations peacekeepers and British forces intervened in 2000-2002 (Abraham, 2001; Keen, 2005).

The effects of the war were appalling. Approximately 30,000 to 75,000 people died of war-related causes, although such estimates are impossible to confirm (Lord, 2000). In total, about half of the population was displaced during the war, either internally or in the neighbouring countries of Guinea and Liberia. Some 257,000 women and girls have reportedly been raped (Ibrahim \& Shepler, 2011). All armed groups took to forcibly recruiting combatants and other helpers, including women and children ; it has been estimated that there were more than 5,000 under-age combatants. About 600 amputees survived the war, but arguably four times as many amputations took place during the war (Lord, 2000). Atrocities took place in all areas of the country, although it is generally acknowledged that the south and east suffered most.

Nowadays many Sierra Leoneans talk about the war as being senseless with regard to the brutal forms of violence employed. The conflict lacked an overall ideology - it was neither religiously or ethnically motivated - and fronts were often unclear. At times neither of the armed groups were fighting each other but indiscriminately attacked civilians (cf. King, 2007; Richards, 1996). The motivations of the fighters were manifold - some might have had revolutionary ideas, others might have been interested in the gains one was able to make belonging to an armed group or saw no other alternative than to join one of the armed groups (Peters \& Richards, 1998). At the same time, structural causes and contributing factors such as widespread corruption, bad governance, and importantly, youth unemployment are widely acknowledged.

\section{Silent Integration}

In the first of three research locations, a small village in Bombali district of northern Sierra Leone, I wondered about the ambiguous use of the word 'ex-combatant' and learned how young men could avoid being labeled as such. Madina has no more than 200 inhabitants and is situated about $15 \mathrm{~km}$ outside of Makeni, the capital of the Northern Province. In Madina, villagers worked mostly on their farms, produc- 
ing rice, potatoes, or bright red chili in order to earn a livelihood. During the war the village was attacked several times by either rebels or rogue government soldiers, forcing people to temporarily leave their houses and stay in the surrounding forests or with relatives in other parts of the country. Most of the villagers had thus not seen the attackers. Many lost their property: houses were burnt down, animals and household items stolen. Some experienced the loss of family members or witnessed atrocities such as severe beatings in the village or during their refuge in other locations.

What was remarkable about this village was that people almost unanimously affirmed that ex-combatants and civilians are now «the same » and strongly avowed that they experienced no problems with each other. An older woman explained to me that «[t]hey have already mixed with us », and to my question of how she felt about this, she added: «it's not a problem ! [...] They have already stopped, they don't touch us anymore» (December 2010). One young man, asked why former combatants and civilians can now live together, simply answered, «because the war is over ». And others have described the relationship even in enthusiastic ways :

I said we are living together now. Why I said we are living together, before this time we didn't have a mind to include the ex-combatants. In what we are doing. But now when we see them somewhere, we will go there and talk with them. [...] All what causes this, is peace. Before this time we don't have such a mind. [...] Some man will come to me and buy palm wine, we sit and pull parables (tell stories), they will drink and we will laugh together, so this was what we were praying for. (Man in his late 20s, December 2010)

Many of the informants in Madina insisted that because former combatants were engaged in the same activities, one could not see a difference : «Before this time, you don't have anywhere to sit [without] somebody scaring you, but for now, any young man, [...] those that have been causing the problems, [...] they and us, you don't even know the difference » (December 2010), a young man told me in an interview together with his best friend who was captured by an armed group during the war.

Yet what puzzled me about these statements is that at the same time many villagers said no known ex-combatants permanently lived in the village. Different from other locations in Sierra Leone, as I will describe below, villagers in Madina were thus not confronted with former perpetrators. Later, however, I did encounter individuals who were associated with former armed groups who lived normal lives in the village, which puzzled me even more.

More confusing still was the villagers reaction when we talked specifically about ex-combatants in the cities, of whom many in Madina spoke rather negatively, displaying prejudices towards ex-combatants common in all parts of Sierra Leone. Generally, the word 'ex-combatant' in Sierra Leone is tied to a range of negative clichés, and many in Sierra Leone have described them as «those young men » hanging out in the cities or bigger towns, who are jobless, living in slums, taking drugs, 
engaged in criminal activities. Since the first organisations of motorbike taxi riding were run entirely by former combatants, motorbike taxi riders are often suspected to be former combatants as well. Although by now motorbike taxi riders are not necessarily ex-combatants, many of them are considered to be dangerous and more often than not suspected to have fought during the war (Bürge, 2011 ; Menzel, 2011). In Madina, these same negative clichés were thus mentioned when I talked with villagers about former combatants in the cities, and it was made clear to me that such excombatants would not be welcome in the village. Thus there seemed to be an important distinction between former combatants who behaved or looked 'rough' and former combatants who behaved 'appropriately' (cf. Menzel, 2011).

A former combatant in Madina, for example, had settled in the village without problems. He had moved to Madina to stay with his friend, and though some villagers knew of his history, such as the mother of his friend, it seemed to be irrelevant in everyday life in the village. How was it possible that people would not 'categorise' this young man as an ex-combatant? I argue here that in some situations it was possible for some young men (and women) to behave in ways that mean they are not considered ex-combatants, regardless if it is known that they were associated with any armed groups or not.

One requirement for successful integration into a community in Sierra Leone is indeed the display of correct behaviour. Integration of strangers, especially young men, is an old practice in many Sierra Leonean regions, as young men were always needed to perform often temporary manual labour in agriculture or mining. Describing the integration of former combatants in nothern Sierra Leone, Rosalind Shaw shows how these older practices were employed. There, integration was most successful if the present behaviour and attitude of ex-combatants was appropriate. Current behaviour thus proved significantly more important to the success of integration than the knowledge of what the given person did during the war. In fact, if the behaviour of ex-combatants was 'humble' enough no further questions would be asked (Shaw, 2010a). The young man in Madina who had been captured by one of the armed groups seemed to agree that this was the best way for society to function : «If the government says you should do [this] and then [...] you don't do it, then you don't want to be under control. And if somebody says he doesn't want to obey the government, it will be a problem for [all] $\gg$ (December 2010). According to Shaw, such a subsumed agency «is crucial for processes of social integration and coexistence (Shawn, 2010a, 125).

That said, a range of scholars have raised important caveats with regard to this integration practice. Importantly, it has been argued that this form of integration actually reinforce the very power relations that led to frustrations among particularly young men before the war as young men are forced into a low status in the community (Peters, 2007 ; Shaw, 2010a ; Stovel, 2008). This may have been one of the rea- 
sons why many former combatants did not choose to return to their communities of origin or other rural communities, as I will discuss below.

So far, I have discussed one practice of coexistence, namely, how former combatants can integrate 'silently' in a given community. Interestingly, the practice somehow blurs the category of 'ex-combatants' as those who behave appropriately are not referred to as ex-combatants anymore. They have become 'invisible' excombatants, while the word 'ex-combatant' is reserved for 'visible' ex-combatants and still connotated negatively. Yet, while such processes of 'silent' integration are likely to have happened in many locations of Sierra Leone, people did not always speak so positively about coexistence as they did in Madina.

\section{Forgive and forget?}

A second location where I spent a considerable amount of time was Tombodu, a larger village with about 3000 inhabitants in the east of Sierra Leone. In Tombodu I learned how villagers found ways to live in coexistence with each other, even though this was no easy task. The phrase 'forgive and forget' was central to this rather pragmatic practice of coexistence.

Tombodu's location in a diamond-rich area of the country made it a critical location for all armed groups during the war, as all fighting factions had at some point or another attempted to mine diamonds for their own profit. Unlike in Madina, where villagers experienced heavy but sporadic attacks, Tombodu was under the control of armed groups for a prolonged time, about three years. Most of the villagers fled to Guinea during the war; some however were not able to flee and thus became subjects or witness of indescribable forms of atrocities. There were several mass graves uncovered after the war, with the most prominent one right in the center of the village. Only a fraction of the inhabitants of Tombodu returned after the war and earn their livelihoods mainly as farmers. Many men are also employed at the diamond digging fields in the area.

In Tombodu, coexistence was perceived as tense. Many of the non-combatant villagers expressed that they did not feel good when they saw former combatants, some of whom were responsible for crimes committed in Tombodu itself. Despite this, however, the villagers unanimously avowed that they lived together peacefully, since there was no other alternative. In this context, the phrase 'forgive and forget' played a large role. The expression became popular after the war when it was initially coined by the government in 1999 and subsequently spread throughout the country. 'Forgive and forget' was preached in churches, mosques and community meetings, and disseminated by local NGOs and I encountered this phrase in all areas in Sierra Leone (cf. Shaw, 2010b).

While in Madina, people often referred to 'forgive and forget' seemingly without giving it a second thought, in Tombodu many examined the expression. Many said 
that you can forgive but never forget, others that you can forget but never forgive. This man, for example, points at the importance of forgiving in creating peace after the war:

But some people are saying we will forgive but not forget. Civilians, rebels, soldiers, all of you come together, the civilians have to bear it, the civilians are the ones who have to bear it, who suffer most, so they have to bear. The rebels where the ones holding the guns, if we say we don't forgive them, we would not have gripped them and the war would not have been over. But we took on the pain, we wanted peace. [...] The civilians agreed to let the war finish. (Man in his 40s, Tombodu, February 2011)

This man illustrated how 'forgive and forget' is far from easy and that civilians are the ones who suffer most in the situation. Yet he also described their motivation: as civilians they wanted peace, so they accepted the price they had to pay for it.

It was interesting that even those informants who expressed personal difficulties with the phrase 'forgive and forget' asserted that it was crucial for peace to hold. 'forgive and forget' may thus be better understood as a 'performance' or an expression for one's willingness to live in coexistence rather than an articulation of real emotions. Anthropologist Michael Jackson's works are particularly insightful here : Describing that such attitudes «are performative in character, rather than mirror the way a person 'actually' thinks or feels » $(2005,369 ; 2004,68)$, Jackson explains how people choose certain strategies to make social life possible rather than put forward one's individual demands. Elswhere Jackson described how social life among the Kuranko in northern Sierra Leone is generally conceived in more practical - and pragmatic - ways: « Kuranko people are far less exercised by the conceptual question, What is in my neighbor's mind ? Than by practicing social wisdom [...] and cultivating copresence - 'greeting,' 'sitting together,' 'working together,' and 'moving as one' » (Jackson, 1998, 12). This hints at an understanding of coexistence as a feature, or even a necessity, of everyday life rather than a choice motivated by inner feelings.

Contrary to its literal meaning thus, if 'forgive and forget' was primarily used as a performative expression it therefore did not necessarily negate that villagers still bore personal feelings of hurt and anger. Rather, many in Tombodu learned to live with the current situation, even if such practices of acceptance can be understood as unfair to the victims of atrocities (Stovel, 2008). The case of this woman demonstrates the contradicting feelings involved:

- Woman : When I see these people I can say that they are my enemies. They are my enemies! You are staying with somebody and they took a knife saying that I am coming to kill you, then you run away. When you come back you see that person, you can still remember that person, the time he took that knife to kill you. So you will always see that person to be your enemy because you see that moment when he was trying to kill you. So they are my enemies.

- FM : Now if you see such a person, nothing will happen, will you do anything with that person? 
— [People sitting around, grumbling :] What will you do ! - Unless you forgive the person. - You won't kill the person, you won't beat him, unless you forget about him.

— Woman : [...] unless you forget about it and sit down. You will sit down together with them but you will never forget the things they have done. You cannot trust them anymore. (Woman in her 60s, Tombodu, January 2011)

The dilemma of the woman becomes clear as she describes how difficult it is to 'forget' when one cannot actually forget: by saying that «you forget about it and sit down with them » she refers to the practice of coexistence which allows civilians and former combatants to live a normal life. When she says «but you will never forget » she refers to her actual memories or feelings. «It is not easy » was perhaps the phrase I heard most often during such conversations.

To recapitulate, I have described how the phrase 'forgive and forget' remains a debated expression but generally represents people's willingness to live in coexistence peacefully. As such, it does not indicate people's real feelings. While in places such as Madina 'forgive and forget' was spoken about rather ingenuously, in Tombodu, where villagers suffered significantly more than elsewhere, sentiments were very mixed.

\section{Urban opportunities}

My third research location was Freetown, the capital of Sierra Leone, where I once again stumbled across the ambiguity of the category 'ex-combatant' but where young individuals, including former combatants, can also find ways to start a new life - perhaps an attraction of large cities in general.

Freetown has the typical fuzziness and chaos of a big city; the city's population has been estimated to have risen to more than a million after the war (the total population of Sierra Leone is about 6 million) (International Crisis Group 2008, 23). In Freetown I heard no shared tales of the war, and individual life stories did not resemble each other as they often did in the rural locations. In addition, people who were in Freetown during the war had experienced different forms of violence than those in the provinces. During the military intervention in January 1999 some areas of the capital were under heavy bombardment and individuals also remembered peacekeepers as perpetrators because they had bombed rebel-'infested' areas indiscriminately.

During my research in Freetown more than ten years after these events the relationship between civilians and former combatants was almost not an issue in the majority of my conversations. Informants simply stated that it did not concern them as former combatants were living in the 'bad areas' of the city. «Freetown now is big, [...] you can stay in the east and the other person in the west », said one man in the neighbourhood where I stayed, and simiarly other informants made statements such as «they are there. So what? » Unlike in places like Tombodu, where former com- 
batants - and often the very perpetrators of atrocities committed - stayed in the same community with civilians, in Freetown, civilians and former combatants appeared to live separately.

Indeed, a large number of former combatants have remained in the urban centres of Sierra Leone and many of those unable to find secure employment can be found in the less affluent neighbourhoods of the city - in Freetown these are mostly the eastern areas of the city. Some former combatants preferred to stay with the members of their armed groups in the cities instead of returning to their communities of origin, and have formed support networks for themselves. Other ex-combatants remained in the cities for another reason: having committed crimes in their communities of origin they felt ashamed to return or were openly discouraged from returning by their relatives or other community members. Some of these networks of former combatants have been linked to incidents of political violence or criminal activities, contributing to an image of the 'dangerous ex-combatant' (Christensen \& Utas, 2008; Menzel, 2011).

Yet despite many of my informants' statements that ex-combatants lived in the 'bad areas' of the city, many former combatants had also integrated into 'normal' neighbourhoods of the town. I had witnessed this in the neighbourhood that I stayed in. During a talk with a neighbour on his veranda he greeted a young man who passed by. I was surprised to learn that, of all places, several of the kamajors who were deployed to 'secure' this area during the war had opted to remain permanently in this neighbourhood once the war was over. "Yes!» the neighbour answered, " you know now, we have forgotten about this war so they are just here, we greet, you see he greeted me, I didn't even see him » (March 2012). The young man was part of a group of kamajors who were assigned to the area and who mistreated some residents in brutal ways. Yet, this knowledge had faded away due to the high mobility in the neighbourhood. The neighbour was one of the few persons who knew about the young men's role during the war. Thus the anonymity of the city might have helped former combatants to integrate, as well as a general display of appropriate behaviour expected from all community members, such as politely greeting their neighbours.

Thus, as mentioned above, the category 'ex-combatant' was used in ambiguous ways. Many of my informants were sceptical towards former combatants, whereas in fact they seemed to refer to the 'bad areas' in the city more generally. Like in Madina, people thus made a difference between 'visible' and 'invisible' excombatants: those who fit an already negative cliché were called ex-combatant, where the personal histories of men who lived normal lives had become irrelevant.

Finally, urban spaces have also opened up new opportunities for young people, including former combatants. The establishment of motorbike taxi riding in all bigger cities in Sierra Leone after the war illustrates how young men, including former combatants, can create new avenues for making a living. Initially established by a 
group of ex-combatants in the southern city of Bo, the business of providing taxi services on motor bikes quickly spread. Today, motorbike taxi riding is a popular profession for young men throughout the country (Bürge, 2011 ; Fithen \& Richards, 2005 ; Peters, 2007).

Such new forms of finding employment in their own networks show that reintegration is not the only option for former combatants. Peters (2007) points out that reintegration also falsely suggests that something has to go back to the way it was, which ignores changes that might have happened in society during or after the time of the war. The case of motorbike taxi riding, for example, could be better described as a process of 'aligning' instead of 'reintegrating' (Peters 2007, 6). That said, however, young men who engage in motorbike taxi riding do confront negative prejudices which they find difficult to counter (Menzel, 2011). On a more general level, the possibilities for all young persons in Sierra Leone to earn a decent livelihood remain extremely scarce.

Thus Freetown presented yet another scenario with regard to coexistence. As in Madina, I soon realised that the category 'ex-combatant' was rather blurry and that even though many civilians avowed that they had no contact with 'ex-combatants', former combatants had nevertheless integrated into society. On the other hand former combatants (and young persons in general) have remained in or migrated to urban centres in Sierra Leone because of the greater possibilities to earn a living there, even if chances to find a secure job remain low. The success of motorbike taxi riding in Sierra Leone is a great example of how young men have created employement for themselves in a postwar society.

\section{Conclusion}

In this article, I have explored three aspects of coexistence in Sierra Leone. First, I have discussed how it is possible for former combatants to (re)integrate into a community based on good behaviour. Second, I described the idea of 'forgive and forget' which is an expression of people's willingness to live in coexistence after the war. Third, I looked at coexistence in a much more anonymous, urban space. The different situations in the various research locations further demonstrate that coexistence can be perceived in significantly different ways within one country. Coexistence in Sierra Leone may mean that, as in Tombodu, people merely accept each other but for the sake of peace will try to avoid conflicts. In Madina on the other hand I could almost sense a convivial atmosphere, as people emphasised that they had 'forgotten' about the war and some former combatants were able to live in the village without any problems. In Freetown, though many of my informants stated that they lived separate from 'ex-combatants', former combatants were able to live normal lives in many areas of the city, far from being labelled in such a way - not least because there seemed to be no relevance to reveal their past in everyday life. 
Recapitulating these observations, the situation in Sierra Leone has proven to be complex with regard to a number of issues. First, the ambiguous use of the word 'ex-combatant' makes this category a rather blurry concept, which was more often than not indicative of a person's social status instead of her or his actual past. Second, and related to this, the question of reintegration becomes equally blurry. If former combatants are using their own networks in order to make a living in nonviolent ways, they may still not be 'integrated' into society but also do not hinder peaceful coexistence. Third, the idea of reconciliation has played a rather marginal role during my research. While 'forgive and forget' is popularly used in Sierra Leone to express the only alternative after war, namely coexistence, few Sierra Leoneans that I met actually spoke of a desire to reconcile with former combatants. This ultimately led me to question the necessity of reconciliation after civil war in this particular context.

On a final note, such observations raise some important questions concerning official reconciliation or reintegration programmes. Notably, a range of official practices of dealing with the past of the civil war had been implemented in Sierra Leone long before I conducted this research, such as the Truth and Reconciliation Commission or the Special Court for Sierra Leone. During my fieldwork however the work of such institutions was not regarded as helpful in reestablishing social relations after the war (cf. Shaw, 2005). Programmes such as the Truth and Reconciliation Commission, geared to reconcile community members, may even run counter to everyday processes of coexistence as by design they often categorise people into 'victims' and 'perpetrators'. With regard to the reintegration of former combatants however, this may be counterintuitive to the informal processes where the ambiguity of such categories such as 'ex-combatant' leaves the possibility of a renegotiation of social roles.

\section{Bibliography}

Abraham, A. (2001). "Dancing with the Chameleon: Sierra Leone and the Elusive Quest for Peace”, Journal of Contemporary African Studies, 19(2), pp.205-28.

BÜrge, M. (2011). "Riding the Narrow Tracks of Moral Life: Commercial Motorbike Riders in Makeni”, Sierra Leone : Africa Today, 58(2), pp.58-95.

Christensen, M. M., Utas, M. (2008). "Mercenaries of Democracy: The 'Politricks' of Remobilized Combatants in the 2007 General Elections, Sierra Leone", African Affairs, 107(429), pp.515-539.

Coulter, C. (2009). Bush Wifes and Girl Soldiers: Women's Lives through War and Peace in Sierra Leone. Ithaca, N.Y., London : Cornell University Press. 
Fithen, C. \& Richards, P. (2005). "Making War, Crafting Peace: Militia Solidarities \& Demobilisation in Sierra Leone", in RichardS, P. (Ed.), No Peace, No War: An Anthropology of Contemporary Armed Conflicts, Oxford: James Currey, pp.117-36.

GBERIE, L. (2005). A Dirty War in West Africa: The RUF and the Destruction of Sierra Leone, Bloomington : Indiana University Press.

IBRAHIM, A. F., SHEPLER, S. (2011). "Introduction : Everyday Life in Postwar Sierra Leone", Africa Today, 58(2), pp.2-16.

International Crisis Group (2008). "Sierra Leone : A New Era of Reform ?", Africa Report No. 143. www.crisisgroup.org/ /media/Files/africa/west-africa/sierraleone/Sierra\%20Leone\%20A\%20New\%20Era\%20of\%20Reform.pdf, accessed 20 October 2009.

JACKSON, M. (2004). In Sierra Leone, Durham and London : Duke University Press.

JACKSON, M. (2005). "Storytelling Events, Violence, and the Appearance of the Past”, Anthropological Quarterly, 78(2), pp.355-375.

JACKSON, M. (1998). Minima Ethnographica: Intersubjectivity and the Anthropological Project, Chicago and London: The University of Chicago Press.

KeEn, D. (2005). Conflict and Collusion in Sierra Leone, Oxford: James Currey Ltd.

KING, N. (2007). Conflict as Integration: Youth Aspiration to Personhood in the Teleology of Sierra Leone's 'Senseless War', Uppsala: Nordiska Afrikainstitutet (36).

LORD, D. (2000). "Introduction: The Struggle for Power and Peace in Sierra Leone", in LORD, D. (Ed.). Paying the Price: The Sierra Leone Peace Process, London : Conciliation Rescources.

MenZel, A. (2011). "Between Ex-Combatization and Opportunities for Peace: The Double-Edged Qualities of Motorcycle-Taxi Driving in Urban Postwar Sierra Leone", Africa Today, 58 (2), pp.96-127.

Peters, K. (2007). "From Weapons to Wheels: Young Sierra Leonean Excombatants Become Motorbike Taxi-riders. Journal of Peace, Conflict and Development", 10, pp.1-23.

Peters, K. \& Richards, P. (1998). "Why we Fight : Voices of Youth Combatants in Sierra Leone", In Africa, 68(2), pp.183-210. 
RICHARDS, P. (1996). Fighting for the Rain Forest: War, Youth \& Resources in Sierra Leone, Oxford : James Currey.

SHAw, R. (2005). "Rethinking Truth and Reconciliation Commissions : Lessons from Sierra Leone", Special Report 130. United States Institute of Peace. www.usip.org/files/resources/sr130.pdf, accessed 31 August 2013.

SHAw, R. (2010a). "Linking Justice with Reintegration? Ex-Combatants and the Sierra Leonean Experiment », in SHAW, R., WALDORF, L. \& HAZAN, P. (Eds.), Localizing transitional justice : interventions and priorities after mass violence, Stanford : Stanford University Press.

SHAw, R. (2010b). "The Production of "Forgiveness": God, Justice, and State Failure in Post-War Sierra Leone", in Clarke, K.M., Goodale, M. (Eds) Mirrors of Justice : Law and Power in the Post-Cold War Era, Cambridge : Cambridge University Press, pp.208-26.

Stovel, L. (2008). “'There's No Bad Bush to Throw Away a Bad Child' : 'Tradition' - Inspired Reintegration in Post-War Sierra Leone”, Journal of Modern African Studies, 46(2), pp.305-24. 